\title{
Alligator Song
}

\section{A Challenge to Spectacle, Product, and Menace}

\author{
Elizabeth Vander Meer
}

Department of Sociology, Philosophy and Anthropology, University of Exeter, United Kingdom evv201@exeter.ac.uk

\begin{abstract}
Alligators were perceived as dangerous by early settlers in Florida, and they also reflected the untamed and potentially untameable Florida wilderness. By the 2oth century, alligator farms capitalized on the thrill of alligator encounters in controlled theme park experiences. Alligators are tamed in the current farm context and valued increasingly for the products that can be derived from their bodies. This anthrozoological investigation of perceptions of Florida alligators explores how farms define alligators and why visitors might accept these particular constructed images of alligators, concluding with a wider view to consider these perceptions of farmed animals in relation to the idea of the nuisance alligator. The discussion is framed by multi-species studies that rest on notions of embodiment and attentiveness, which in this case push the importance of alligator experience and agency to the foreground.
\end{abstract}

\section{Keywords}

alligator farms - domestication - embodiment - Florida - hunting

\section{Introduction}

The multi-species studies of Buller (2013) and Warkentin (2010) provide a frame for discussion of perceptions of American alligators (Alligator mississippiensis) and how these reptiles are defined in the context of Florida alligator farms and within notions of nuisance. This perspective also begins to tease out what these definitions might mean for individual alligators. Buller (2013) 
investigates farm environments and asserts that human and farm animal "affective relations are complicated by an enduring duality, that of the animal as individual and the animal as multitude/herd/mass" (pp. 156-157). The individual disappears in the mass, or the "type" being farmed. The antidote to this disappearing is a view that exhibits Milton's (2005) egomorphism.

Egomorphism relies on embodied experience that can provide access to the subjective world of individual nonhuman animals (Buller, 2013). Milton (2005) acknowledges the importance of social and cultural contexts to perceptions but argues that we "understand things by perceiving characteristics in them"; this is in contrast to the anthropomorphic "attributing characteristics to things" (pp. 260, 268). Cultural contexts (learned meanings) may "cover up" individual animals when they are experienced, but a human being can directly perceive another animal as similar or "like me," in the sense of exhibiting emotional states, intentionality, and personality (Milton, 2005, p. 263); the animal is not passive but is an active participant in interactions and knowledge production. Other animals are perceived, legitimately, as more than symbol, object, or metaphor.

Warkentin (2010) presents a praxis of paying attention to other animals that is reliant on embodiment, which adds strength to the idea of egomorphism because of its clear focus on making the individual animal visible in terms of both those characteristics "like me" and those "not like me." We can begin to know animal experience through careful attentiveness and then be able to respond ethically in relation to other animals. Both sameness and difference must be acknowledged, rather than seeing sameness where there may be, or is, difference, which amounts to an uncritical anthropomorphism; attending to an animal other in this way is aided by an understanding of evolutionary continuity and biological diversity.

As Milton (2005) notes, "when observing non-human animals the potential for error is greater [than when we observe other human beings] because different species have different emotional responses" (p. 265). At the same time, we remain open and thus "we still treat the inner world of non-human animals as available and perceivable, just as we treat each other's moods as available and perceivable" (Milton, 2005, p. 265). Keul's (2013) embodied approach to human-alligator interactions in the context of swamp tours in Louisiana will also provide an important reference point in the following virtual exploration of three Florida alligator farms, in discussion of perceptions of nuisance alligators captured in recent studies, and when considering alligators as agential and responsive beings. A history of perceptions of alligators and of alligator farms in Florida begins this enquiry. 


\section{Historical Background}

Newly arrived European inhabitants in Florida expressed both fear and loathing towards alligators, but these attitudes should be located within a wider view of this new land as a wild and hostile place (Barrow, 2010; Carr, 1994; Downey, 1934). Many large predators, such as gray wolves (Canis lupus) and mountain lions (Puma concolor), were hunted to near extirpation across the United States by Europeans, especially after settlers had established themselves in communities with domesticated animals (Bruskotter \& Wilson, 2014; Large \& Rutherford, 2014; Dunlap, 1991). Alligators gained a reputation for being bloodthirsty man-eaters, a reputation stoked over several centuries by popular figures such as French artist Jacques Le Moyne in the 16th century and later William Bartram in the 18th century (Barrow, 2009; Barrow, 2010). It was not until the 2oth century that more balanced, or accurate, accounts of alligator behavior began to appear. Most notably, McIllenny revealed alligators are more likely to run from an encounter with a human than to attack (Barrow, 2010).

The 2oth century also brought with it greater commodification of alligators. By the 1950 and 1960s, populations of alligators in the southeast plummeted due to overhunting for skins (Hayman, Harvey, Mazzotti, Israel, \& Woodward, 2014). Despite US Fish Commission concern about alligator population declines as early as the late 1800 s, "the species failed to find support during the turn-of-the-century wildlife conservation movement that rescued the bison and numerous North American plume birds from the brink of extinction ... relatively few Americans seemed concerned about their plight" (Barrow, 2009, pp. 271-272). Herpetologist Archie Carr and fellow preservationists called for a halt to the commodification of the American alligator, pushing successfully for protection of the species under the Endangered Species Act in the late $1960 \mathrm{~s}$ (Barrow, 2009); Carr reflected a minority perspective, one based on a naturalist's view of these reptiles.

The growth of alligator farms in Florida ultimately led to further commodification of alligators. Alligator farms were at first roadside tourist attractions featuring safe encounters with the crocodilians, but "farm" seemed a misnomer at the time, since the businesses did not kill and then process alligators into products for consumption. Alligator farms had proliferated throughout Florida by the 1930s (Barrow, 2010). Mays (2009) provides a detailed historical account of Gatorland from its beginnings in 1949, under the leadership of Owen Godwin. She traces the shift in tourists' priorities, as interest in visiting Florida beaches was supplanted by a preference for visiting theme parks. Godwin designed Gatorland to function as a theme park, and 
Mays notes that he "delivered the themed experience of Florida in spectacular fashion" (p. 515).

Much to the dismay of Carr and other preservationists, the Florida state government allowed resumption of trade in alligator products and the killing of nuisance alligators from 1977, after it appeared that alligator populations had rebounded (Barrow, 2009). Some alligator farms within the state, such as Gatorland, increased revenue by actually farming the alligators for skin and meat, while also continuing to provide public entertainment such as the viewing of alligators in enclosures and in wrestling shows (Mays, 2009). St. Augustine Alligator Farm, which first opened in 1893, displays alligators and other native wildlife but has never killed and processed their alligators, so it maintains the ethos of a zoological park (St. Augustine Alligator Farm, n.d.). Farms dedicated to breeding, killing, and processing alligators, without the public theme park face, were also created after 1977. A non-traditional model has developed that falls within the Florida Fish and Wildlife Conservation Commission (FWC) category of alligator farm. In this case, businesses breed alligators on their land; facilitate controlled hunting by members of the public; and process alligators killed on the hunts at their facilities, with some also processing alligators killed off-site by permitted hunters (FWC, n.d. -e).

Alligator farms that process the reptiles into products are part of a state-run alligator management program (FWC, n.d. -b). They fulfil consumer demand for alligator products and increase state revenue. Farms are also meant to ease pressure on wild alligator populations, to avoid a recurrence of population declines from overhunting. The Statewide Alligator Harvest Program contributes to population management as well (FWC, n.d. -h). The FWC establishes alligator management units annually where seasonal public hunting is allowed through a permit system. The American alligator has special legal status as a species similar in appearance to other threatened species, so the creature is afforded federal protection but the state can still manage populations (FWC, n.d. -d). The FWC presents and promotes a utilitarian perspective in state management of species deemed common and/or invasive. The FWC has recently applied this view to Florida black bears, whose population at only 3,00o individuals has been considered adequate for limited yearly bear hunts, which commenced in October 2015 (FWC, n.d. -f).

The FWC estimated the value of hides and meat from farmed and wildcaught alligators processed in 2014 to be in the region of $\$ 16,600,605$; that monetary amount is derived from 43,356 alligator skins and 636,605 pounds of meat (FWC, n.d. -c). Alligator farms produced 25,113 hides and 211,573 pounds of meat, while 18,243 skins and 425,032 pounds of meat were processed from 
wild alligators. "Nuisance" alligators contribute to wild figures. In 2014, 6,706 alligators were captured, killed, and processed as a result of nuisance complaints (FWC, n.d. -g). Sixty-three alligator farms are currently licensed by the FWC (FWC, n.d. -b); 30 farms have permits to collect wild eggs and hatchlings on designated land, and farm licenses include stipulations regarding receipt of eggs and/or hatchlings.

Only six alligator farms are open widely to the public as theme park tourist attractions. Two traditional theme park farms, Gatorama and Everglades Alligator Farm, as well as the non-traditional Townsend and Sons farm and hunting outfitter, provide windows into the ways in which alligators are defined in farmed contexts. As farms open to the public for visitation, they must market themselves by constructing a certain image of alligators for human consumption. These images, constructed through online advertising and presentation, will be introduced here along with online responses to alligator farm experiences.

\section{Gatorama and Everglades Alligator Farm: A "Traditional" Experience}

Gatorama, situated in Moore Haven, south central Florida, opened in 1957 and is a family-operated business. It provides a "traditional" farm experience for visitors (Gatorama, n.d. -a). The owners have created what they describe as a taste of Old Florida, which includes strolls down wide wooden boardwalks that lead visitors through a small zoo featuring alligators as well as crocodiles, bobcats, panthers, and other Florida wildlife. Gatorama offers "thrills" in the form of animal shows and interactive events, where men wrestle alligators and children catch juvenile alligators in a wading pool; the juvenile alligators' jaws are taped shut during the event.

The Hatching Festival is a key element of the tourist attraction, and considered part of the organisation's educational program (Gatorama, n.d. -c). The Festival takes place yearly in August, and visitors are given the chance to hold alligator eggs as they hatch. Gatorama appears to market the event to families with young children. Meat also takes center stage at Gatorama, as it is processed at the farm and sold to tourists on the premises, as well as online through advertisements for various "exotic" meat packages (Gatorama, n.d. -b).

Visitors' reactions to Gatorama can be glimpsed through posted online reviews; business research has referenced TripAdvisor to determine the effects of reviews on hotel performance (Tuominen, 2011), for instance, and it has been 
cited as containing "detailed, rich and relevant data for use by consumers in their travel planning" (O'Connor, 2008, p. 47). Reference to TripAdvisor can begin to expose visitors' perceptions across a broad timeframe, with recognition of the limitations (this is merely a glimpse) and the influence of such reviews on subsequent visitors. Some visitors to Gatorama have posted reviews on TripAdvisor $(2015 \mathrm{~b})$ to rate the attraction as excellent, very good, average, poor, or terrible; attention here is paid to the highest and lowest ratings.

One hundred thirteen individuals posted from 2008 to February 2015, giving the attraction an excellent or very good rating, with many of them mentioning the hatching alligators as a highlight of the experience. Some also commented on their children's excitement at chasing and catching juvenile alligators in the pool, the excitement of the wrestling show, and enjoyment at seeing so many alligators in one place. One of the four terrible ratings included concern regarding the enclosures for the animals other than the alligators, as these were considered too small and barren.

Everglades Alligator Farm, in Homestead Florida, lies just on the edge of the Everglades National Park (Everglades Alligator Farm, n.d. -a). It mirrors Gatorama in terms of its key elements, such as a nature trail around the farm for viewing of alligators and other wildlife, alligator shows featuring wrestling, and photo opportunities with baby alligators. This farm differs from Gatorama in that it does not have meat- or skin-processing facilities, even though it boasts a population of more than 2,00o alligators; instead, it sells alligator eggs to other farms within the state. Everglades Alligator Farm emphasizes the value of their airboat rides into the Everglades as well as alligator-feeding sessions (Everglades Alligator Farm, n.d. -b). These sessions will involve 500 or more crocodilians in a breeding pond leaping over each other to catch food such as dead rats thrown in by keepers.

Three hundred forty-two individuals posted excellent or very good reviews of Everglades Alligator Farm on TripAdvisor (2015a) from 2008 to February 2015. These reviews included many positive comments about the airboat rides, entertaining shows, number of alligators available for viewing, and opportunity to hold baby alligators. There were 31 poor ratings and 21 terrible ratings. Some terrible ratings were given due to the duration of the airboat rides, but several pointed to animal welfare concerns. One, for example, described a baby alligator, mouth taped, lifted out of a rubbish bin, and adult alligators in shows that seemed so groggy they might have been drugged. Such treatment was not considered humane. Another individual who gave the attraction a terrible rating called the animals' living conditions appalling, while another urged potential visitors not to go if they cared about animals. 


\section{Townsend and Sons: Thrill of the Hunt}

Townsend and Sons, located in LaBelle, Florida, since 1996, is a farm and outfitter for hunting experiences on 400,000 acres of private land (Townsend and Sons, n.d. -a). They are the destination of some so-called nuisance alligators, who then breed on the land, providing the company with hatchlings who can be sold to other farms (Gillis, 2014). These alligators also become the trophy prey for paying hunters. Townsend and Sons run their own processing plant for alligators killed during their facilitated hunts, and for alligators killed during the annual 11-week FWC-managed public alligator hunt (Gillis, 2014). The facilities process meat into vacuum-packed cubes, skins into wallets and other accessories, and they also provide taxidermy services (Townsend and Sons, n.d. -d). After the hunt on company land, hunters will leave with pre-packed alligator meat (not the meat of the animal they killed) and are later sent "their" alligator's skin in whatever form they have requested.

The company guarantees that each hunter will be able to kill an alligator during the hunt, as it is a highly controlled experience (Townsend and Sons, n.d. -b). Novice hunters can take part, guided by the owner's highly skilled and experienced sons. Prospective hunters have a choice of weapons, including rifle, pistol, bow, and harpoon. Prices for the hunt vary depending upon the size of alligator the hunter is hoping to kill. Images of triumphant hunters kneeling beside dead, bloodied animals fill the promotional pages of the Townsend and Sons website and social media pages.

A notable photograph in the photo gallery shows a family of four, with three individuals sitting on the backs of the alligators they have killed (Townsend and Sons, n.d. -c); a little girl sits with her father on one alligator. The outfitters promote a "family friendly hunting experience." After the highly publicized killing of Cecil the lion in Zimbabwe by an American trophy hunter in July 2015, Townsend and Sons were quick to make a distinction between their alligator hunting and trophy hunting, calling alligator hunting "a necessary part of animal conservation" (Townsend and Sons, 2015). Prior to Cecil's killing, this link between hunting and conservation had not been mentioned on the website.

The Townsend and Sons social media pages contain posts and comments from satisfied customers who thank the company for a wallet or mounted alligator part from "their" alligator, or call the experience "the hunt of a lifetime" and congratulate Townsend's sons for delivering the alligator as promised (Townsend and Sons Facebook, 2015). These customers share videos and pictures from their hunt experiences, most often men posed kneeling beside 
dead alligators and holding the animals' mouths agape. The pages also advertise company attractions, such as a live, six-foot alligator displayed at a deer, turkey, and waterfowl expo. The alligator lies in a glass tank, just slightly longer than the creature's six feet; the top of the tank is removable so that visitors can touch the reptile inside.

\section{Alligators in the Foreground:Traditional Farm and the Sport/ Trophy Hunt}

\section{Traditional Alligator Farm}

How does the farming context define alligators and potentially make their experiences as individuals disappear? Industrial farming requires significant control of domesticated animals in the production process (Clutton-Brock, 1989). These animals are rendered passive and trapped en masse yet react to their environments as individuals, alive to experience. Ingold (2000) describes the domination that defines pastoralist societies and those reliant on domestication. He points out that domesticated animals transform into property: "Property is conceived here as a relation between persons (subjects) in respect of things (objects).... Human beings, as social persons, can own; animals, as natural objects, are only ownable" (p. 64). It should be noted that not all farming methods involve such control (Hurn, 2012), and there are equally other relationships that occur based on human respect and admiration for alligators, as expressed by the wildlife biologist or ethologist, who has come to know alligator-ness and perhaps even the uniqueness of individual alligators (Barrow, 2009; Carr, 1994).

Alligator farms serve to semi-domesticate the reptiles, a control that can render them less frightening and more subservient as part of their conversion into products; Jaclin (2013) has explored this state of being not-wild-yetnot-domesticated in the context of black market exotic pets. The Institute of Food and Agricultural Sciences (IFAS) informational document, "Alligator Production in Florida" (Lane \& King, 1996), uses terminology that converts the animal irrevocably into commodity for human consumption; it is one of the FWC's key public resources introducing the practice of alligator farming. The paper describes growing alligators to harvest, and the need for research to increase hatch rates, to develop methods for more rapid growth, and to discover new alligator products. The alligator is no longer a wild animal; the reptile joins the ranks of cows, chickens, and other "livestock." The commodification evident in the case of domesticated farm animals takes hold so that the alligators 
are reduced to objects that are property by Ingold's definition. We see the loss of the individual in the mass of objects being farmed.

The IFAS document contains no reference to the welfare of the farmed alligators. Tsovel's (2005) assertion regarding agricultural texts holds true here; he states that they "ignore any experiential aspect of [the animals'] lives beyond 'productivity'-related issues" (p. 246). This perspective has been revealed poignantly by Davis (2010) in the context of the conditions in which factoryfarmed chickens must live. A poultry industry veterinarian suggests using the term "beak deconditioning" rather than debeaking, to divest the act of its cruelty to the individual animal, and Davis (2010) argues that "every effort is made to obscure and dent the reality of chicken experience" (p. 26o).

Several issues can be highlighted in the specific context of Gatorama and Everglades Alligator Farm, if alligators are pushed to the foreground as individuals with agency and sentience. Alligator wrestling is a thrilling spectacle for tourists visiting the farms, but this spectacle results in extreme stress for the animal; wrestling involves continued provocation of the alligator, who is often dragged by the tail and then subjected to beatings and the brute force of the wrestler (Animal Rights Foundation of Florida (ARFF), n.d.). It can be argued that these actions keep the alligator in a state of fear and defensiveness, while also causing physical harm; the alligator also shows agency and sentience in cases where the individual animal's actions depart from the wrestler's script, resulting in human injury. Audiences may walk away with a false impression of alligator behavior, as this glimpse could reinforce belief in an innate aggressiveness in alligators. Increased stress levels have been documented in alligators living in overcrowded conditions such as those apparent at many alligator farms (Elsey, Joanen, McNease, \& Lance, 1990).

\section{Trophy Hunt within the Farm Context}

Townsend and Sons is classified as an alligator farm by the FWC but sport or trophy hunting in part delivers alligators to their processing facilities. How then, are these reptiles further defined by this kind of hunting within the farmed context? The practice of sport hunting may be less about obtaining meat and more about the experience, the excitement, and unpredictability of the chase, or as Hurn (2012) highlights, it could involve the animal transformed to symbol within a larger social or political conflict. Marvin (2006) emphasizes that the death of the animal may not be as significant as the experience: "the killing brought about in hunting is disorderly and certainly not inevitable, because it is based on the lack of continuous control of wild animals by humans" (p. 24). Marvin argues that, "at the moment of aiming and pulling the trigger, 
that individual bird is the hunter's bird," which is an emotional possession of sorts as well as a physical possession of the animal's dead body (p. 25).

Olson (2002) provides a different and valuable understanding of the acts perpetrated by sport hunters. She identifies a rhetorical homology when she compares sport hunting, hate crimes, and stranger rape:

I contend that late twentieth-century American sport hunters, 'hate criminals,' and stranger rapists create a non-consensual relationship with a party selected not as a unique individual but by virtue of convenience combined with that party's observable marks of differential group classification and that they justify impersonal violence within this nonconsensual relationship through homologous symbol use. (p. 218)

The relationship between human and nonhuman animals, when considering Olson's reading of sport hunting, stands in stark contrast to the "gift in the animal" described as integral in some hunter-gather societies (Hurn, 2012; Nadasdy, 2007). Ultimately, the animals killed (wild animals) become the hunter's property in Marvin's account, just as domestic animals are owned, and this aligns with Olson's observation of at least some sport hunters' desires to physically dominate the animal "other." But the hunters acknowledge the agency of the prey in both Marvin's and Olson's accounts. The animal can fight or take flight to evade "capture."

Unlike domesticated animals killed in an abattoir, where facilities are often kept out of sight (Burt, 2001, for instance), the killing of alligators in the Townsend and Sons' sport hunting context takes place in "full view" and is glorified, even advertised; alligators are defined in terms of this spectacle. In the case of Townsend and Sons, there appears to be a lack of perceived reciprocity between human and nonhuman animal. A subsistence drive also does not lie behind these hunting acts. The hunter's interest in the chase rather than the kill, explained by Marvin (2006), equally has no bearing here, as the company guarantees a kill and thus the hunt is highly controlled. Townsend and Sons ultimately divest the alligator of the agency to escape once the hunt begins. The activity becomes part of today's consumptive wildlife tourism (Dobson, 2012), which includes big game and canned hunting.

This objectification through spectacle inevitably leads to what could be and has been considered inhumane treatment of alligators during sport hunts. The Animal Rights Foundation of Florida (ARFF) campaigns for the humane hunting of alligators during the public hunt, raising serious concerns about use of harpoons and crossbows to shoot restraining lines into the animals; these weapons are also used by Townsend and Sons. Once restrained, the struggle 
between hunter and reptile can sometimes last for an hour or more, according to ARFF (n.d.). The hunter finally kills the alligator by firing a bang stick (firearm cartridge) into the animal's head at close range. ARFF contends that bang sticks may not immediately kill the alligators but they do mortally wound them, resulting in a painful and protracted death. The alligator who has been placed in a glass tank at the expo has little room to move, and crowds of visitors are visible constantly. It would be reasonable to conclude that the alligator experiences a state of stress while in these conditions; reptiles are vertebrates and as such have the neuroarchitecture to be able to experience pain as well as stress responses (Boyle, 2009; Elsey et al., 1990).

\section{Human Perceptions of Alligators: Theme Park Experiences}

Why might such treatment and interaction be accepted by visitors to the traditional alligator farm, and why do individuals seek out the hunt? The majority of visitors to the alligator farms who posted on TripAdvisor and hunters at Townsend and Sons recounted what the experience meant for them, the excitement and novelty, without an expressed regard for the impact of that experience on the alligators; they did not appear to consider or see the animals beyond entertainment and human use value. Mays (2009) asserts that theme parks provide an experience with a particular appeal:

Theme park visitors are seeking an experience that takes them out of their ordinary environment and plunges them into a world of fantasy, nature, or adventure. One of the selling points of a theme park is that it can deliver the illusion of adventure in a very controlled environment ... a risky activity that is risk-free. (p. 515)

Theme parks, then, can obscure individual animals held captive within that space. The alligators are part of an exotic fantasy or illusion, and therefore human visitors may fail to relate to them as individuals. Keul (2013) contends that alligators "live in spaces that are (in the Western world) socially constructed as antipodes to human habitat. In many ways, their worlds and bodies are oppositional to humanity" (p. 948). Townsend and Sons can be included in this theme park category with the highly controlled hunt, which provides a risky activity risk-free; risk-free seems substantiated by the fact that children are allowed on hunts (no fatalities reported), and the hunts are advertised as family-friendly experiences. The farm as theme park makes alligator individuals disappear on multiple levels. 
Broader pervasive cultural influences may be at play as well, that exhibit a lack of attentiveness to other animals. Speciesism, as defined by Ryder (2010) and manifest widely in the Euro-American context, could be seen as a key and fundamental underlying reason for acceptance and enjoyment of this way of relating. But there could be sentiment more specific to the American cultural context that allows for such comfortableness with this kind of interaction. Lawrence (1984) explored the American rodeo from an anthrozoological perspective and noted that, "rodeo embodies the frontier spirit as manifested through the aggressive and exploitative conquest of the West ... [it] re-enacts the 'taming' process whereby the wild is brought under control" (p. 7). Alligator wrestling, catching juveniles, and holding eggs as they hatch represent the taming of a wild apex predator.

Hunting driven by domination and/or entertainment value, in which the struggle of the animal is sensationalized, has been perpetuated in contemporary us popular media on the reality television show aired nationally called "Swamp People," and with statements like, "everyone wants to kill an alligator" (Gillis, 2014; Keul, 2013). The popular reality series "Gator Boys" follows trappers in Florida who relocate, or keep for show, alligators deemed nuisances, rather than killing them; the trappers do appear to care about the animals, but wrestling stunts and taunting provoke the alligators to react more dramatically for the camera, and this approach feeds into a narrative of alligator-human conflict/battle as spectacle and thrilling entertainment (Animal Planet, n.d.). A link has been made between such sensationalizing and an increase in the number of hunters requesting permits from the FWC for the 11-week public hunt in Florida, and a rise in demand for alligator meat and other products (Gillis, 2014). The FWC is responsible for allowing and encouraging farming and hunts as part of their alligator management program.

We can identify a small subset of visitors to Everglades Alligator Farm who did foreground the experience for the alligators in posts to TripAdvisor. Keul (2013) describes embodied experience during swamp tours in Louisiana: "people imagine alligators not as a completely alien other, but as a hybrid body, able to inform any-body," so they are able to "see past cultural constructions and identify with a co-body" (pp. 943, 948). In the same sense, those visitors to the farm who expressed concern about the alligators' welfare saw the crocodilians as responsive, active, and in this case, subjugated individuals. The attentiveness exhibited here is explained by Warkentin (2013): "embodiment enables the expression of ethical comportment toward others, while also providing a kind of empathic approximation of the experience of others in our midst" (p. 103). 


\section{Nuisance Complaints: Alligators "Out of Control"}

Stepping out of the controlled context of theme parks, we can step into the wider, surrounding context of "wild" Florida and begin to consider how alligators are perceived by residents in comparison to farmed encounters. Alligators in symbolic form are embraced in the state of Florida, not only in theme parks. They have been named the official state reptile (Florida Department of State, 2015), and they serve as the mascot for the popular University of Florida football team, the Gators. But, as human developments encroach upon marshland and bodies of water inhabited by these crocodilians, face-to-face human encounters with alligators increase (Hayman et al., 2014; Eversole, Henke, Ogdee, Wester, \& Cooper, 2014). Human-wildlife conflict occurs as a result of expanding human settlements in many parts of the world (Dickman, 2010).

The FWC (n.d. -d) acknowledges difficulties with counting alligators but provides a population estimate of 1.3 million, including hatchlings. Deaths from alligator attacks are rare. The number of people killed by alligators since 1948 totals 22 (FWC, 2013). Eversole et al. (2014) note the significant rise in nuisance complaints in Florida from $1987(4,917)$ to 2006 (18,307); since then, complaints to the FWC have fluctuated, decreasing to 13,599 in 2014 (FWC, n.d. -g). Hayman et al. (2014) investigated complaints to begin to identify factors that would cause individuals to contact the FWC. Importantly, this research revealed a disconnect between general positive attitudes towards alligators and the behavior of complaining about nuisance alligators. Situational factors and related beliefs about risk were key to understanding nuisance complaints.

Hayman et al. (2014) describe the importance of structural fixes to address situational factors, such as regulations near water that limit construction or pets roaming freely. They also describe the FWC's program of targeted harvest areas (THAs) that allows private landowners and property managers to contact authorized alligator trappers directly to have nuisance alligators removed from their land; many survey participants felt that private landowners should be allowed to remove all alligators from their lands, as a right. Both Hayman et al. (2014) and Eversole et al. (2014) express concerns that nuisance complaints could lead to over-harvesting and thus affect the health of populations in the state. Hayman et al. (2014) call for stronger communication campaigns from the FWC that provide clear understandings of risk but also the benefits to living with alligators. Bruskotter and Wilson (2014) emphasize further the need for focus on benefits, arguing that too much focus on risk may actually increase negative perceptions and actions. 
Living with alligators, or any large predator, will never be a completely riskfree experience and this must be acknowledged, but risk may become exaggerated in the minds of some residents, especially after highly publicized deaths or attacks. The "Gator Boys" series may also perpetuate fear through the trappers' sensational approach despite the fact that they do not kill the crocodilians. Dickman (2010) maintains that, "the concept and understanding of risk, as well as reactions to it, are heavily influenced by social and cultural perceptions, values, history and ideology particularly with regard to ideas of what the world 'should' be like" (p. 459). She highlights the influence of popular media in risk perceptions associated with certain predator species, for instance.

It is important to consider how the term "nuisance" is being defined. In the case of alligators, is it based on close proximity alone, is it based on witnessed aggressive behavior, or both? The term nuisance is problematic because its use could involve a disregard for the fact that human settlements are consuming alligator habitat in Florida; alligators do not stay where they "should be," away from homes and backyards. Peterson, Birkhead, Leong, Peterson, and Peterson (2010) fundamentally question the use of "human-wildlife conflict," concluding that this adversarial language gets in the way of co-existence. A perspective that asks for greater attentiveness to individual alligators calls for a shift in language.

\section{Conclusion: Redefining Alligators?}

Florida has gained a reputation as the theme park mecca of the United States, and perhaps of the world. IFAS (Lane \& King, 1996) has placed emphasis on the need for research to discover new alligator products, and the 21st century has delivered an expansion in the possible uses of these animals, reinforcing the continued "need" for farming (see Ayalasmayajula, Gallo, Dufreche, Zappi, \& Bajpai, 2012). Alligators defined as nuisance add further complexity to perceptions of these crocodilians, perceptions which all appear to contribute to the covering up or disappearance of individual animals. Alligators within the controlled experience of the theme park farms are reduced to products and spectacular risk-free thrills. Alligators roaming freely in the midst of human habitation are reduced to dangerous, out of place, out of control predators. Focus on the benefits associated with the identity of alligators, for instance, as apex predators and ecosystem engineers (Rosenblatt et al., 2013), can be important in moderating or dampening perceptions of risk as well as perceptions of alligators as mere products or entertainment. 
Increasing public understandings of observed species characteristics that begin to redefine individual alligators in more recognizable, less alien, terms would also be valuable; this emphasizes potential continuity rather than heightening difference. Research by Doody, Burghardt, and Dinets (2012) challenges the notion that reptiles belong to a "non-social" taxon and highlights the diversity of sociality apparent in these vertebrate ectotherms. While most reptiles do not exhibit complex parental care of young, crocodilians are the exception, the American alligator among them (Deitz \& Hines, 1980). Researchers recently made the groundbreaking discovery that crocodilians use objects to lure prey, a clear example of tool use, in part from observations of alligators in Florida (Dinets, Brueggen, \& Brueggen, 2013). Rosenblatt et al. (2013) identified differences in individual behavior in top predator populations, including alligator populations; an individual may be more bold or shy, aggressive or passive, and so on. Bekoff (2007a, 2007b) pioneers research into the mental and emotional lives of animals and includes aquatic animals as worthy of such understanding.

Further anthrozoological research is needed to continue to explore relationships and interactions that occur between humans and alligators in the Florida context, with an eye on bringing alligators into the foreground. Further research could elaborate on embodied experience to better understand the reasons some visitors to alligator farm attractions see and relate to alligators as suffering individuals in the midst of the theme park experience. Trialing an educational program to attempt to shift perceptions of nuisance would also be beneficial. Continued work on embodiment and attentiveness in the vein of Keul (2013) has the potential to challenge perceptions of alligators as spectacle, product, and menace. Alligators have a voice that could be heard more widely in the way that Carr (1994) heard it:

The song of the alligator is a vast, rumbling growl that rolls up through the mist of warm dawns like something half sound and half shaking the earth. One alligator singing alone is a moving thing to hear. Three bellowing in chorus seem to take over the world, to be doing too great a singing for any pond to hold and stay the same. (p. 122)

\section{References}

Animal Planet. (n.d.). Gator boys. Retrieved October 24, 2015, from http://www.animal planet.com/tv-shows/gator-boys/. 
Animal Rights Foundation of Florida, ARFF. (n.d.). Florida alligators. Retrieved February 14, 2015, from http://animalrightsflorida.org/Alligators.html.

Ayalasomayajula, S., Gallo, A., Dufreche, S., Zappi, M., \& Bajpai, R. (2012). Potential of alligator fat as a source of lipids for biodiesel production. Industrial and Engineering Chemical Research, 51(4), 2166-2169.

Barrow, Jr., M.V. (2009). Dragons in distress: naturalists and bioactivists in the campaign to save the American alligator. Journal of the History of Biology, 42, 267-288.

Barrow, Jr., M.V. (2010). The alligator's allure: changing perceptions of a charismatic carnivore. In D. Brantz (Ed.), Beastly Natures: Animals, humans and the study of history. Charlottesville, VA: University of Virginia Press.

Bekoff, M. (2007a). The emotional lives of animals. Novato: New World Library.

Bekoff, M. (2007b). Aquatic animals, cognitive ethology and ethics: questions about sentience and other troubling issues that lurk in turbid water. Diseases of Aquatic Organisms, 75, 87-98.

Boyle, E. (2009). Neuroscience and animal sentience. Retrieved March 7, 2015, from http://www.ciwf.org.uk/includes/documents/cm_docs/2009/b/boyle_20o9_neuro science_and_animal_sentience.pdf.

Bruskotter, J.T., \& Wilson, R.S. (2012). Determining where the wild things will be: using psychological theory to find tolerance for large carnivores. Conservation Letters, 7 , 158-165.

Buller, H. (2013). Individuation, the mass and farm animals. Theory, Culture and Society, $30(7 / 8), 155^{-175}$.

Burt, J. (2001). The illumination of the animal kingdom: the role of light and electricity in animal representation. Society and Animals, 9(3), 203-228.

Carr, A. (1994). A naturalist in Florida: a celebration of Eden. New Haven, CT: Yale University Press.

Clutton-Brock, J. (Ed.). (1989). The walking larder: patterns of domestication, pastoralism and predation. London, $\mathrm{U}$ : Unwin Hyman.

Davis, K. (2010). Chicken-human relationships: from procrustean genocide to empathic anthropomorphism. Minding the Animal Psyche, 83, 255-280.

Deitz, D.C., \& Hines, T.C. (1980). Alligator nesting in north-central Florida. Copeia, $1980(2), 249-258$.

Dickman, A.J. (2010). Complexities of conflict: the importance of considering social factors for effectively resolving human-wildlife conflict. Animal Conservation, 13, 458-466.

Dinets, V., Brueggen, J.C., \& Brueggen, J.D. (2013). Crocodilians use tools for hunting. Ethology, Ecology and Evolution, 27(1), 74-78.

Dobson, J. (2012). Ethical issues in trophy hunting. In O. Monfakkir \& P. Burns (Eds.), Controversies in Tourism. CABI. 
Doody, J.S., Burghardt, G.M., \& Dinets, V. (2012). Breaking the social-non-social dichotomy: A role for reptiles in vertebrate social behavior research? Ethology, n19, 1-9.

Downey, T.E. (1934). The Huguenot settlements in Florida, 1562-1565. Masters Thesis. Loyola University, Chicago, paper 153.

Dunlap, T. (1991). Saving America's wildlife: ecology and the American mind, 1850-1990. Princeton, NJ: Princeton University Press.

Elsey, R., Joanen, T., McNease, L., \& Lance, V. (1990). Stress and plasma corticosterone levels in the American alligator-relationships with stocking density and nesting success. Comparative Biochemical Physiology, 95A(1), 55-63.

Everglades Alligator Farm. (n.d. -a). Home page. Retrieved February 1, 2015, from http://www.everglades.com/.

Everglades Alligator Farm. (n.d. -b). Attractions. Retrieved February 1, 2015, from http://www.everglades.com/attractions.php.

Eversole, C.B., Henke, S.E., Ogdee, J.L., Wester, D.B., \& Cooper, A. (2014). Nuisance American alligators: an investigation into trends and public opinion. HumanWildlife Interactions, $8(1), 5^{-21}$.

Florida Department of State. (2015). Florida state reptile. Retrieved March 6, 2015, from http://dos.myflorida.com/florida-facts/florida-state-symbols/state-reptile/.

Florida Fish and Wildlife Conservation Commission. (2013). Alligator bites on people in Florida. Retrieved February 21, from http://myfwc.com/media/310203/Alligator GatorBites.pdf.

Florida Fish and Wildlife Conservation Commission. (n.d. -a). Alligator facts. Retrieved February 21, 2015, from http://myfwc.com/wildlifehabitats/managed/alligator/ facts/.

Florida Fish and Wildlife Conservation Commission. (n.d. -b). Alligator farming. Retrieved February 21, 2015, from http://myfwc.com/wildlifehabitats/managed/ alligator/farming/.

Florida Fish and Wildlife Conservation Commission. (n.d. -c). Combined harvest summary. Retrieved October 24, 2015, from http://myfwc.com/media/310185/ alligator_combined_value.pdf.

Florida Fish and Wildlife Conservation Commission. (n.d. -d). FAQs. Retrieved February 21, 2015, from http://myfwc.com/wildlifehabitats/managed/alligator/faqs/.

Florida Fish and Wildlife Conservation Commission. (n.d. -e). Florida alligator farm contact information. Retrieved October 24, 2015, from http://myfwc.com/ media/1297868/Alligator_Farms_table.pdf.

Florida Fish and Wildlife Conservation Commission. (n.d. -f). Florida black bear. Retrieved October 24, 2015, from http://myfwc.com/wildlifehabitats/managed/ bear/. 
Florida Fish and Wildlife Conservation Commission. (n.d. -g). Nuisance alligator harvest summary. Retrieved October 24, 2015, from http://myfwc.com/media/310272/ Alligator_SNAP_sum.pdf.

Florida Fish and Wildlife Conservation Commission. (n.d. -h). Statewide alligator harvest program. Retrieved October 24, 2015, from http://myfwc.com/wildlifehabitats/ managed/alligator/harvest/.

Gatorama. (n.d. -a). Home page. Retrieved February 1, 2015, from http://gatorama .com/.

Gatorama. (n.d. -b). Gator meat. Retrieved February 1, 2015, from http://gatorama .com/product-category/gatormeat/.

Gatorama. (n.d. -c). Hatching history. Retrieved February 1, 2015, from http://www .hatchingfestival.com/about-us-2/.

Gillespie, A. (1987). American wildlife in symbol and story. Knoxville, Tn: University of Tennessee Press.

Gillis, C. (2014). Florida gator hunt creates market for hides, meat. Retrieved February 21, 2015, from http://www.usatoday.com/story/money/business/2014/og/o1/ fla-gator-hunt-creates-market-for-hides-meat/14884577/.

Hayman, R.B., Harvey, R.G., Mazzotti, F.J., Israel, G.D., \& Woodward, A.R. (2014). Who complains about alligators? Cognitive and situational factors influence behaviors toward wildlife. Human Dimensions of Wildlife, 19(6), 481-497.

Hurn, S. (2012). Humans and other animals: cross-cultural perspectives on humananimal interactions. London, UK: Pluto Press.

Ingold, T. (2000). The perception of the environment: essays on livelihood, dwelling and skill. London, uk: Routledge.

Jaclin, D. (2013). In the (bleary) eye of the tiger: an anthropological journey into jungle backyards. Social Science Information, 52(2), 257-271.

Keul, A. (2013). Embodied encounters between humans and gators. Social \& Cultural Geography, 14(8), 930-953.

Lane, T.J., \& King, F.W. (1996). Alligator production in Florida. Institute of Food and Agricultural Sciences, University of Florida, VM-52.

Large, S.G., \& Rutherford, M.B. (2014). Large carnivore conservation: integrating science and policy in the North American West. Chicago, IL: University of Chicago Press.

Lawrence, E.A. (1984). Rodeo: an anthropologist looks at the wild and the tame. Chicago, IL: University of Chicago Press.

Marvin, G. (2006). Wild killing: contesting the animal in hunting. In the Animal Studies Group, Killing Animals. Urbana, IL: University of Illinois Press.

Mays, D. (2009). Gatorland: survival of the fittest among Florida's mid-tier tourist attractions. The Florida Historical Quarterly, 87(4), 509-539.

Merchant, M., Roche, C., Elsey, R., \& Prudhomme, J. (2003). Antibacterial properties of serum from the American alligator (Alligator mississippiensis). Comparative Biochemistry and Physiology Part B: Biochemistry and Molecular Biology, 136(3), 505-513. 
Milton, K. (2005). Anthropomorphism or egomorphism? The perception of nonhuman persons by human ones. In J. Knight (Ed.), Animals in Person: cultural perspectives on human-animal intimacies. Oxford, UK: Berg.

Nadasdy, P. (2007). The gift in the animal: the ontology of hunting and human-animal sociality. American Ethnologist, 34(1), 25-43.

O'Connor, P. (2008). User-generated content and travel: a case study on Tripadvisor. com. In P. O'Connor, W. Hopken, \& U. Gretzel (Eds.), Information and communication technologies in tourism. Proceedings of the International Conference in Innsbruck, Austria.

Olson, K. (2002). Detecting a common interpretive framework for impersonal violence: the homology in participants' rhetoric on sport hunting, 'hate crimes' and stranger rape. Southern Communication Journal, 67(3), 215-244.

Peterson, M.N., Birkhead, J.L., Leong, K., Peterson, M.J., \& Peterson, T.R. (2010). Rearticulating the myth of human-wildlife conflict. Conservation Letters, 3, 74-82.

Rosenblatt, A.E., Heithaus, M.R., Mather, P., Matich, P., Nifong, J., Ripple, W.J., \& Silliman, B. (2013). The roles of large top predators in coastal ecosystems: new insights from long term ecological research. Oceanography, 26, 156-167.

Ryder, R. (2010). Speciesism again: the original leaflet. Critical Society, 2(Spring), 1-2.

St. Augustine Alligator Farm. (n.d.). Retrieved October 24, 2015, from www.alligatorfarm.com/our-history.

Townsend and Sons Everglades Outfitters. (2015). Gator hunting is not akin to killing Cecil the lion. Retrieved October 24, 2015, from http://info.flgatorhunts.com/blog/ gator-hunting-is-not-akin-to-killing-cecil-the-lion.

Townsend and Sons Everglades Outfitters. (n.d. -a). About us. Retrieved October 24, 2015, from http://flgatorhunts.com/about-us/.

Townsend and Sons Everglades Outfitters. (n.d. -b). Alligator hunts. Retrieved February 21, 2015, from http://flgatorhunts.com/alligator-hunts/.

Townsend and Sons Everglades Outfitters. (n.d. -c). Photos. Retrieved October 24, 2015, from http://flgatorhunts.com/photos/.

Townsend and Sons Everglades Outfitters. (n.d. -d). Processing facilities. Retrieved February 21, 2015, from http://flgatorhunts.com/processing-facilities/.

Townsend and Sons Facebook. (2015). Retrieved February 28, 2015, from https://www .facebook.com/tsevergladesoutfitters.

TripAdvisor. (2015a). Everglades Alligator Farm user reviews. Retrieved February 28, 2015, from http://www.tripadvisor.com/Attraction_Review-g34222-d131001-Reviews -Everglades_Alligator_Farm-Flamingo_Florida.html\#REVIEWS.

TripAdvisor. (2015b). Gatorama user reviews. Retrieved February 21, 2015, from http:// www.tripadvisor.co.uk/ShowUserReviews-g34537-d255277-r246253732-Gatorama -Palmdale_Florida.html.

Tsovel, A. (2005). What can a farm animal biography accomplish? The case of Portrait of a Burger as a Young Calf. Society \& Animals, 13(3), 245-262. 
Tuominen, P. (2011). The influence of TripAdvisor consumer-generated travel reviews on hotel performance. University of Hertfordshire Business School Working Paper, UK.

Warkentin, T. (2010). Interspecies etiquette: an ethics of paying attention. Ethics \& the Environment, 15(1), 101-121. 